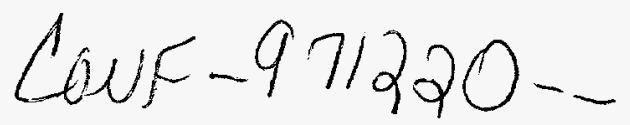

\title{
EMBRITTLEMENT OF AUSTENITIC STAINLESS STEEL WELDS
}

\author{
S. A. David and J. M. Vitek \\ Metals and Ceramics Division \\ Oak Ridge National Laboratory \\ Oak Ridge, TN 37831-6095
}

Austenitic stainless steels are extensively used in several industries such as power generation (both conventional and nuclear) and chemical and petrochemical industries because of their excellent corrosion resistance as well as their good mechanical properties. Austenitic stainless steel weld metal normally has a duplex structure that contains varying amounts of ferrite. It is recognized that if sufficient ferrite (5-10\%) is in the weld metal, the ferrite will effectively prevent hot-cracking. ${ }^{(1-3)}$ The origin of ferrite and the role of ferrite in preventing hot-cracking has been addressed elsewhere. ${ }^{(1-7)}$ The ferrite phase in austenitic stainless steel welds has been found to exist in four distinct, types of morphologies, namely vermicular, acicular, and globular. ${ }^{(8)}$ Although ferrite in austenitic stainless steel weld metal has a beneficial effect in preventing hot-cracking during welding, when exposed to elevated temperatures during service, the duplex structure of austenite $\gamma+$ ferrite $\delta$ embrittles extensively, leading to a degradation of mechanical properties.

The microstructure of type-308 austenitic stainless steel weld metal containing $\gamma$ and $\delta$ and ferrite is shown in Figure 1. Typical composition of the weld metal is $\mathrm{Cr}-20.2, \mathrm{Ni}-9.4, \mathrm{Mn}-1.7$, Si$0.5, \mathrm{C}-0.05, \mathrm{~N}-0.06$ and balance $\mathrm{Fe}$ (in wt \%). The origin of the duplex $(\gamma+\delta)$ microstructure is the nonequilibrium nature of the transformations that follow weld pool solidification and subsequent cooling of the weld metal to room temperature. An earlier study $y^{(4)}$ showed the solidification sequence in type-308 stainless steel weld metal consisted of primary crystallization of $\delta$-ferrite with subsequent envelopment of $\delta$-ferrite by austenite $(\gamma)$ and a $\delta-\gamma$ transformation continuing below the solidus. As a result, ferrite is often located along the cores of the primary and secondary dendrite arums and is enriched in chromium and depleted in nickel. Other investigations by Suutala et al ${ }^{(5)}$ and Takalo $\mathrm{at}^{\mathrm{a} \mathrm{l}^{(6)}}$ have identified the mode of freezing and the resulting microstructures of austenitic stainless steel welds as a function of $\mathrm{Cr} / \mathrm{Ni}$ equivalent ratios.

\section{Embrittlement at Temperatures $\geq 550^{\circ} \mathrm{C}$}

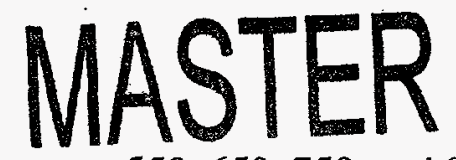

When type-308 stainless steel welds were aged at temperatures $550,650,750$, and $850^{\circ} \mathrm{C}$ for times up to $10,000 \mathrm{hrs}$, a number of changes were observed in the as-welded microstructure. ${ }^{(9,10)}$ In the early stages of aging, precipitation of $\mathrm{M}_{23} \mathrm{C}_{6}$ carbide was observed at the original austenite/ferrite interface (Figure 2). At the same time, the ferrite was found to dissolve to a limited extent, leaving the residual ferrite more enriched in chromium and depleted in nickel. Upon aging further, ferrite transformed to sigma phase (Figure 3). The electron micrograph in Figure 3 reveals the structure after 100 -hr aging wherein the original austenite/ferrite boundary is clearly marked by the $\mathrm{M}_{23} \mathrm{C}_{6}$ precipitates and the ferrite has transferred to sigma phase. Figure 3 also shows the receded sigma boundary due to the dissolution of ferrite. The continuous network of carbides is the key to the degradation of mechanical properties of the weld metal. ${ }^{(9 \cdot 12)}$ The sequences of 


\section{DISCLAIMER}

This report was prepared as an account of work sponsored by an agency of the United States Government. Neither the United States Government nor any agency thereof, nor any of their employees, makes any warranty, express or implied, or assumes any legal liability or responsibility for the accuracy, completeness, or usefulness of any information, apparatus, product, or process disclosed, or represents that its use would not infringe privately owned rights. Reference herein to any specific commercial product, process, or service by trade name, trademark, manufacturer, or otherwise does not necessarily constitute or imply its endorsement, recommendation, or favoring by the United States Government or any agency thereof. The views and opinions of authors expressed herein do not necessarily state or reflect those of the United States Government or any agency thereof. 


\section{Disclamigr}

Portions of this document may be illegible in electronic imsge produets. Images are produced from the best available original doeconeret 
events were the same at all temperatures investigated. However, the kinetics of the transformations were faster at higher temperatures.

\section{Embrittlement at Temperatures $\leq 550^{\circ} \mathrm{C}$}

Changes in the as-welded microstructure observed upon aging of type-308 stainless steel weld metal at $400^{\circ} \mathrm{C}$ or $475^{\circ} \mathrm{C}$ for times up to $5,000 \mathrm{hrs}$ were significantly different from those described above. Aging at temperatures less than $550^{\circ} \mathrm{C}$ showed no evidence of the ferrite-to-sigma phase transformation. However, precipitation of $\mathrm{M}_{23} \mathrm{C}_{6}$ carbide at the austenite/ferrite interface was found. During the initial stages of aging, within the ferrite, a fine-scale spinodal decomposition of ferrite into iron-rich $\alpha$ and chromium-rich $\alpha^{\prime}$ phases was observed ${ }^{(13,14)}$ as shown in Figure 4 . This decomposition of ferrite in the weld is similar to observations made in some ferritic steels. ${ }^{\text {(15-18) }}$ This transformation has been found to embrittle the ferritic steel. Also within the ferrite, in addition to the spinodal decomposition, abundant precipitation of a nickel-rich silicon phase, namely GPhase, was observed. ${ }^{(14)}$ Determination of the ferrite hardness as a function of aging time and temperature indicated extensive hardening of the ferrite during aging. ${ }^{(13)}$ Also during the early stages of aging there is a shift in the Charpy impact ductile-brittle transition temperature (DBTT) as shown in Figure 5. With extended aging, a drop in the upper shelf energy was also observed. These observations can be attributed to the extensive solid-state transformations that occur within the ferrite during aging.

\section{Summary}

Exposure of austenitic stainless steel welds to elevated temperatures can lead to extensive changes in the microstructural features of the weld metal. On exposure to elevated temperatures over a long period of time, a continuous network of $\mathrm{M}_{23} \mathrm{C}_{6}$ carbide forms at the austenite/ferrite interface. Upon aging at temperatures between $550-850^{\circ} \mathrm{C}$, ferrite in the weld has been found to be unstable and transforms to sigma phase. These changes have been found to influence mechanical behavior of the weld metal, in particular the creep-rupture properties. For aging temperatures below $550^{\circ} \mathrm{C}$ the ferrite decomposes spinodally into $\alpha$ and $\alpha^{\prime}$ phases. In addition, precipitation of G-phase occurs within the decomposed ferrite. These transformations at temperatures below $550^{\circ} \mathrm{C}$ lead to embrittlement of the weld metal as revealed by the Charpy impact properties.

\section{Acknowledgments}

The authors would like to thank E. K. Ohriner and Q. Han for reviewing the manuscript. Research is sponsored by the Division of Materials Sciences, US Department of Energy, under contract DE-AC05-96OR22464, with Lockheed Martin Energy Research Corp. 


\section{References}

1. J. C. Borland and R. N. Younger, British-Welding J. 7(1):22-60 (1960).

2. F. C. Hull, Welding J. 38(4):176-s (1959).

3. Y. Arata, F. Matsuda, and S. Katayama, Trans. Jpn. Welding Res. Ins. 5(2):35-51 (1976).

4. S. A. David, G. M. Goodwin, and D. N. Braski, Weld. J. 58(11):330s-336s (1979).

5. N. Suutala, T. Takalo, and T. Moisio, Metall. Trans. 10A:512-514 (1979).

6. T. Takalo and T. Moisio, Metall. Trans. 10A:1183-1190 (1979).

7. W. T. DeLLong, Welding J. 53(7):273-s-286-s (1974).

8. S. A. David, Welding J. 60(4):63s-71s (1981).

9. J. M. Vxttek and S. A. David, Weld. J. 63:246s-253s (1984).

10. J. M. Vitek and S. A. David, Weld. J. 65:106s-111s (1986).

11. J. M. Vitek, S. A. David, and V. K. Sikka, Weld J. 71:421s-435s (1992).

12. S. S. Babu, S. A. David, J. M. Vitek, and M. K. Miller, Met. \& Mats. Trans A, 27A:763 (1996).

13. S. A. David, J. M. Vitek, J. R. Keiser, and W. C. Oliver, Welding J. 66:235s-240s (1987).

14. J. M. Vitek, S. A. David, D. J. Alexander, J. R. Keiser, and R. K. Nanstad, Acta Met. Mater. 39(4):503-516(1991).

15. R. M. Fisher, E. J. Dulis, and K. G. Carroll, Trans. AIME 197:690-695 (1953).

16. R. O. Williams and H. W. Paxton, J. Iron Steel Inst. 185:358-374 (1957).

17. D. Chandra and L. H. Schwartz, Metall. Trans. 2A:511-519 (1971).

18. J. Nishizawa, M. Hasebe, and M. Ko, Acta. Metall. 27:817-828 (1979). 

年

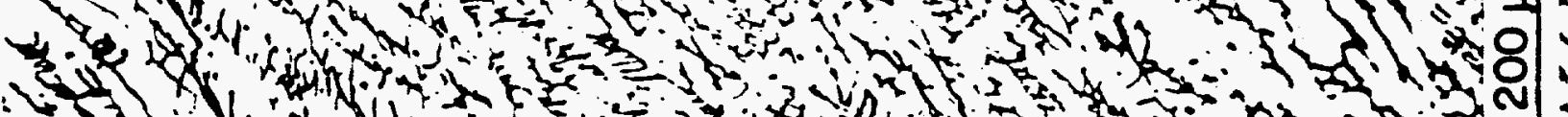

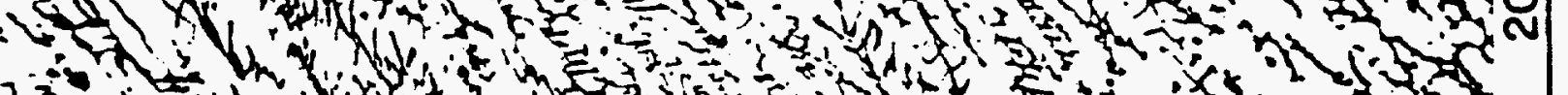

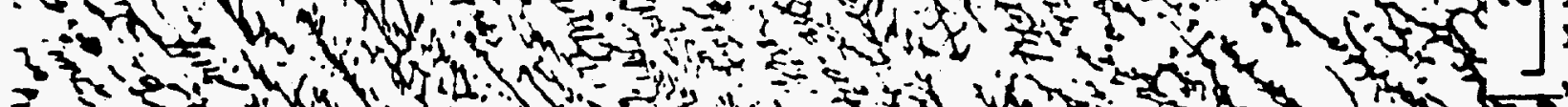
F-27t $=5$ -

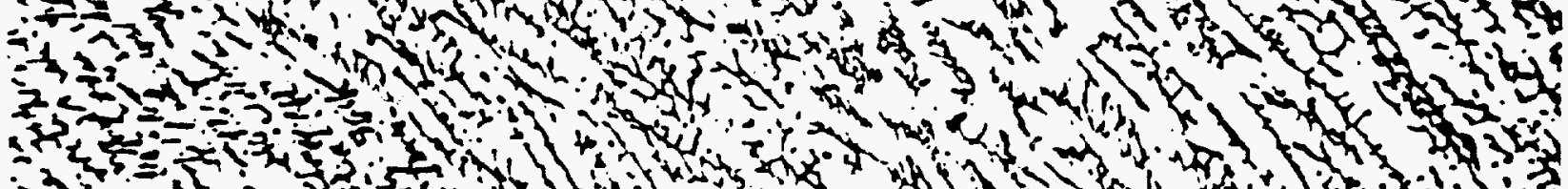
2. al a 4 to

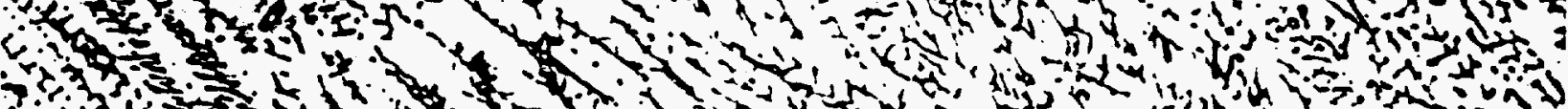

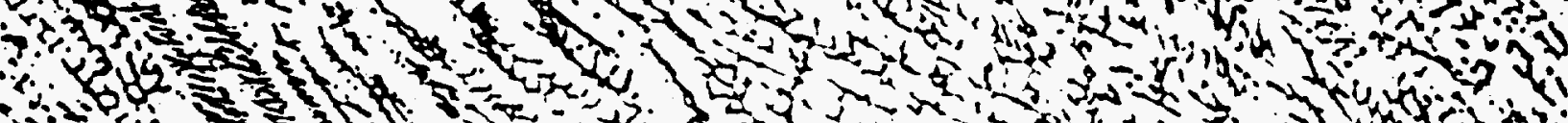

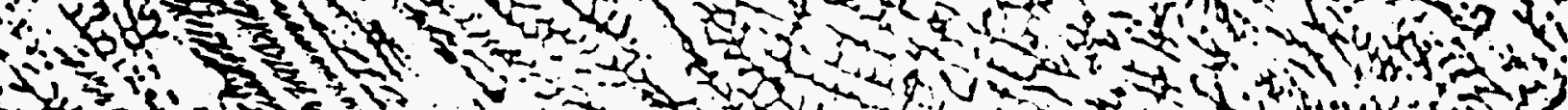

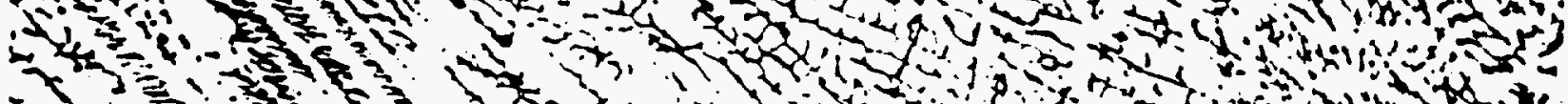

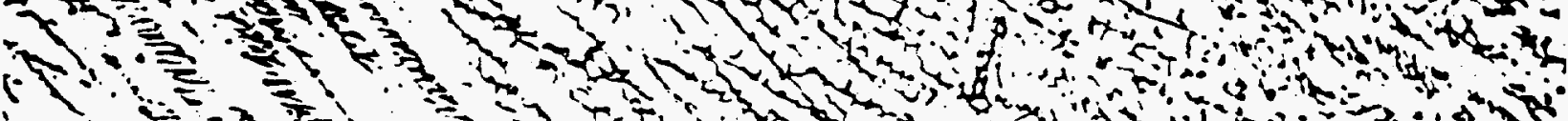

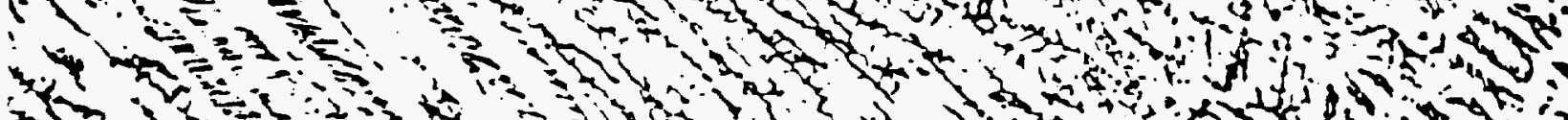

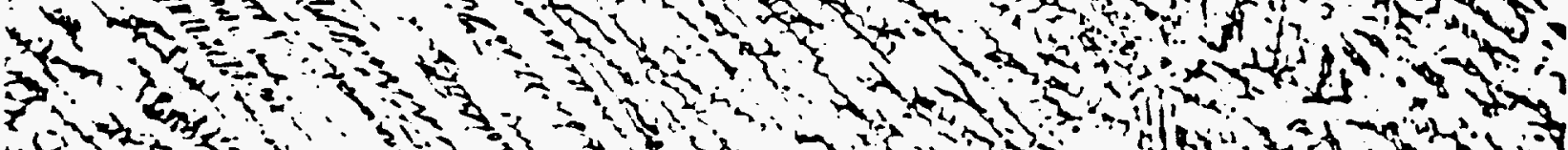

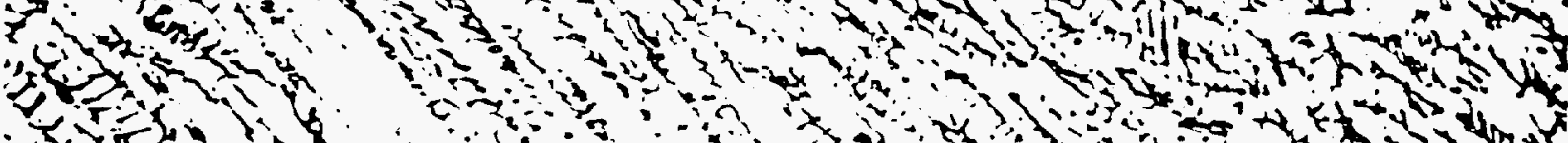

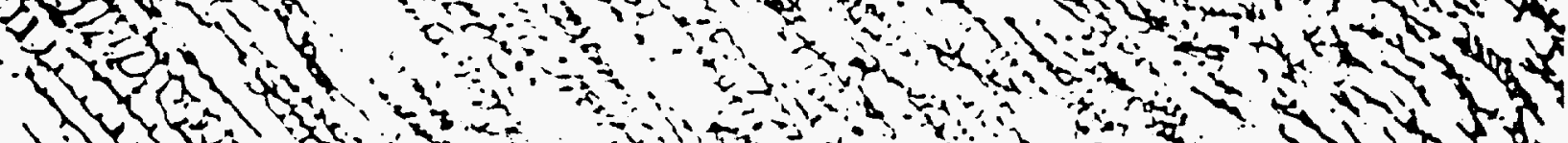

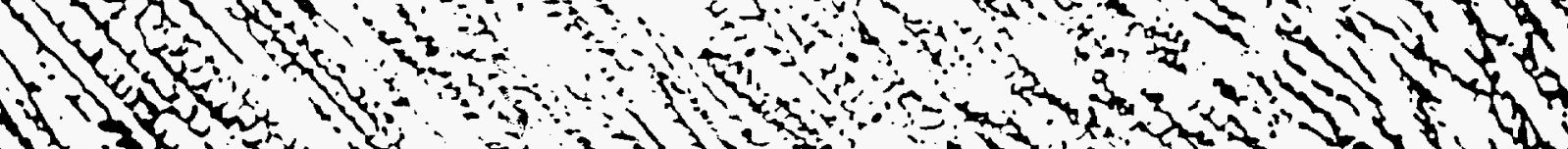

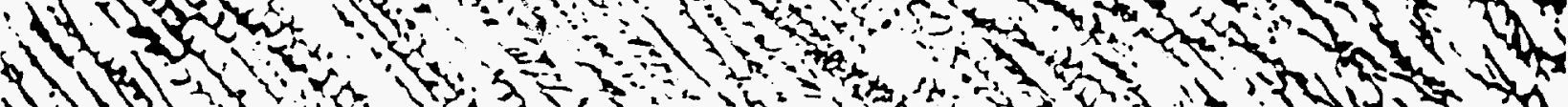

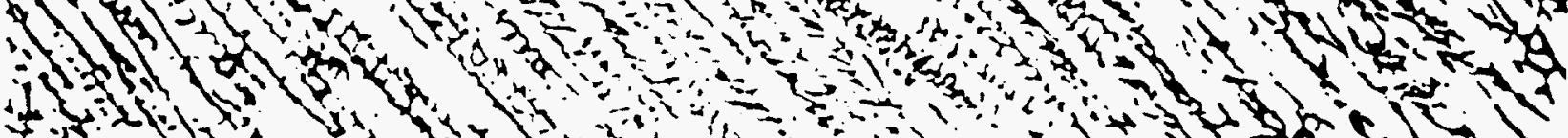
Het

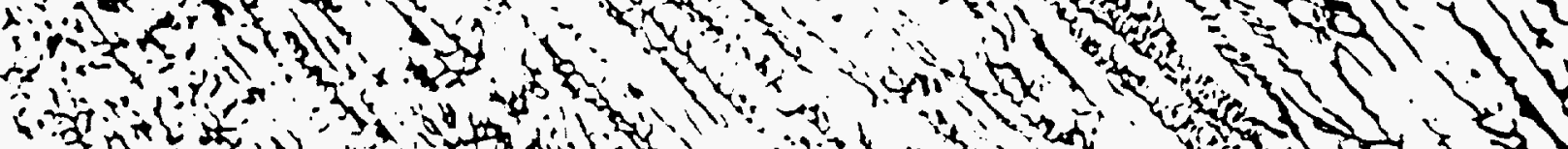
(n)

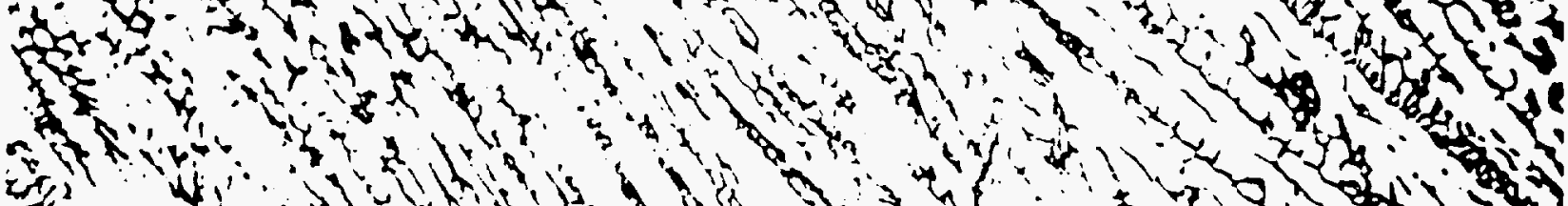

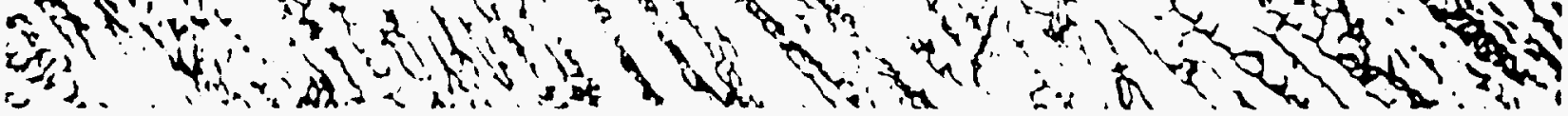




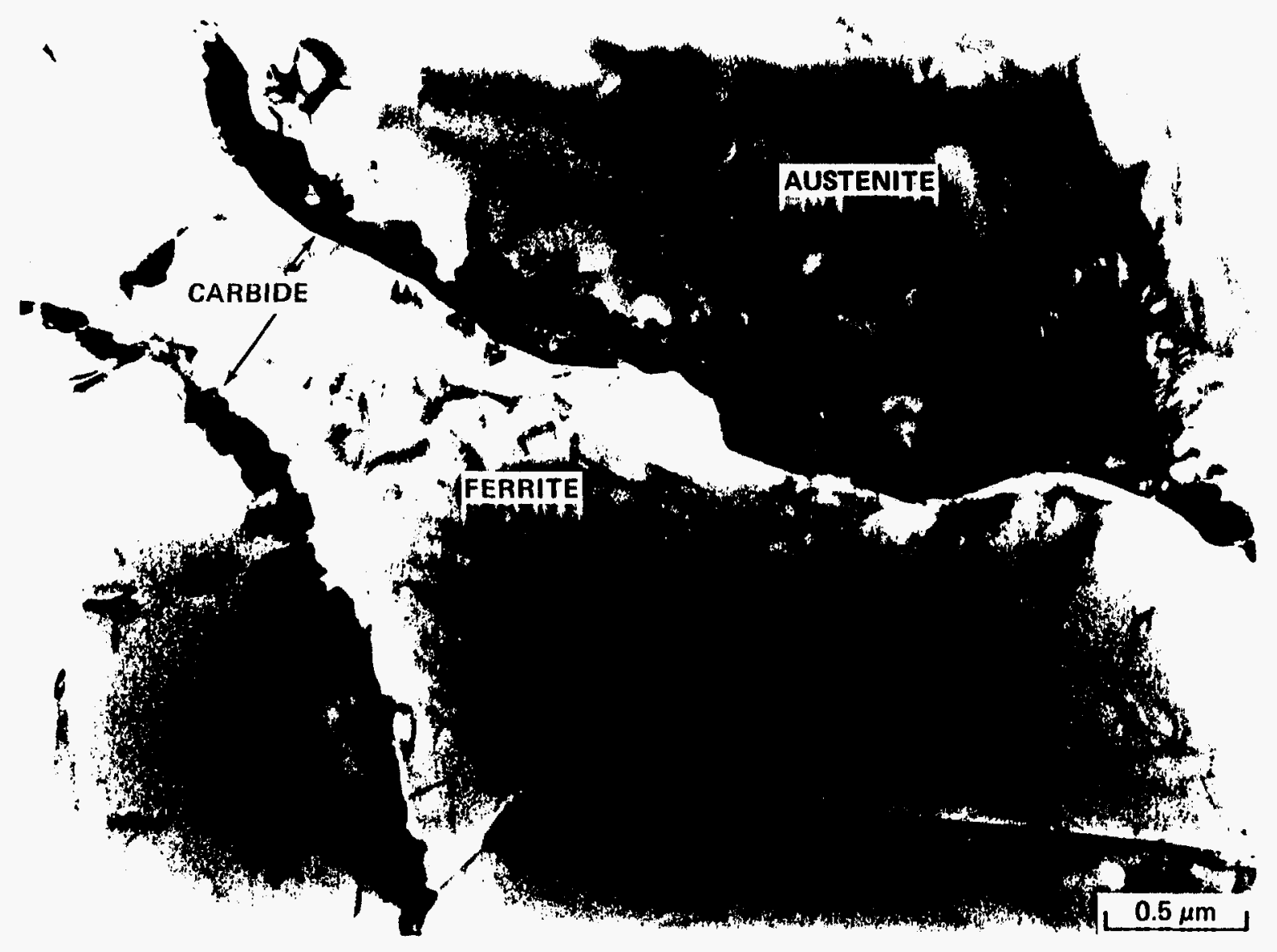

Figure 2. Electron micrograph of type 308 stainless steel weld aged at $650^{\circ} \mathrm{C}$ for $18 \mathrm{~min}$ 


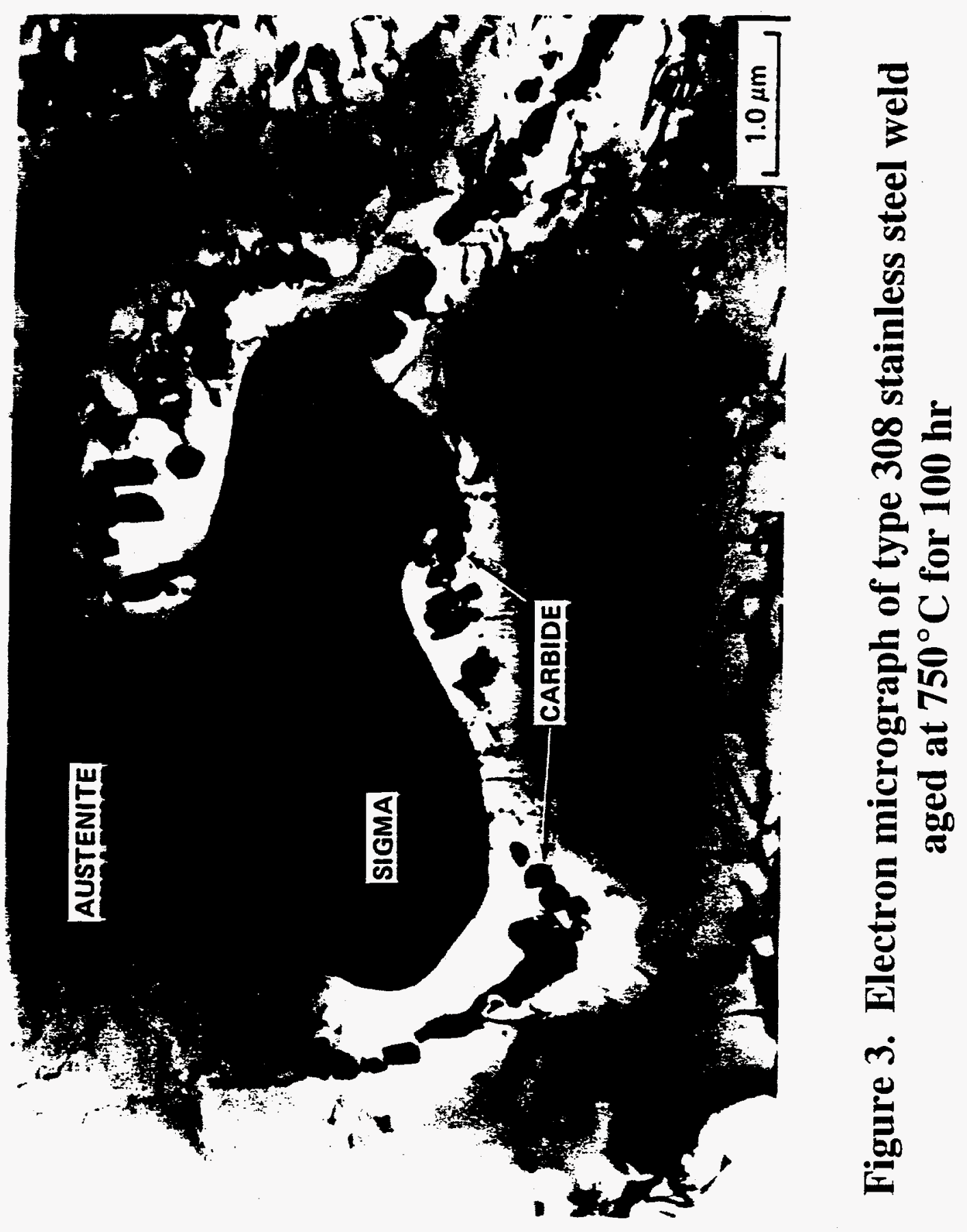




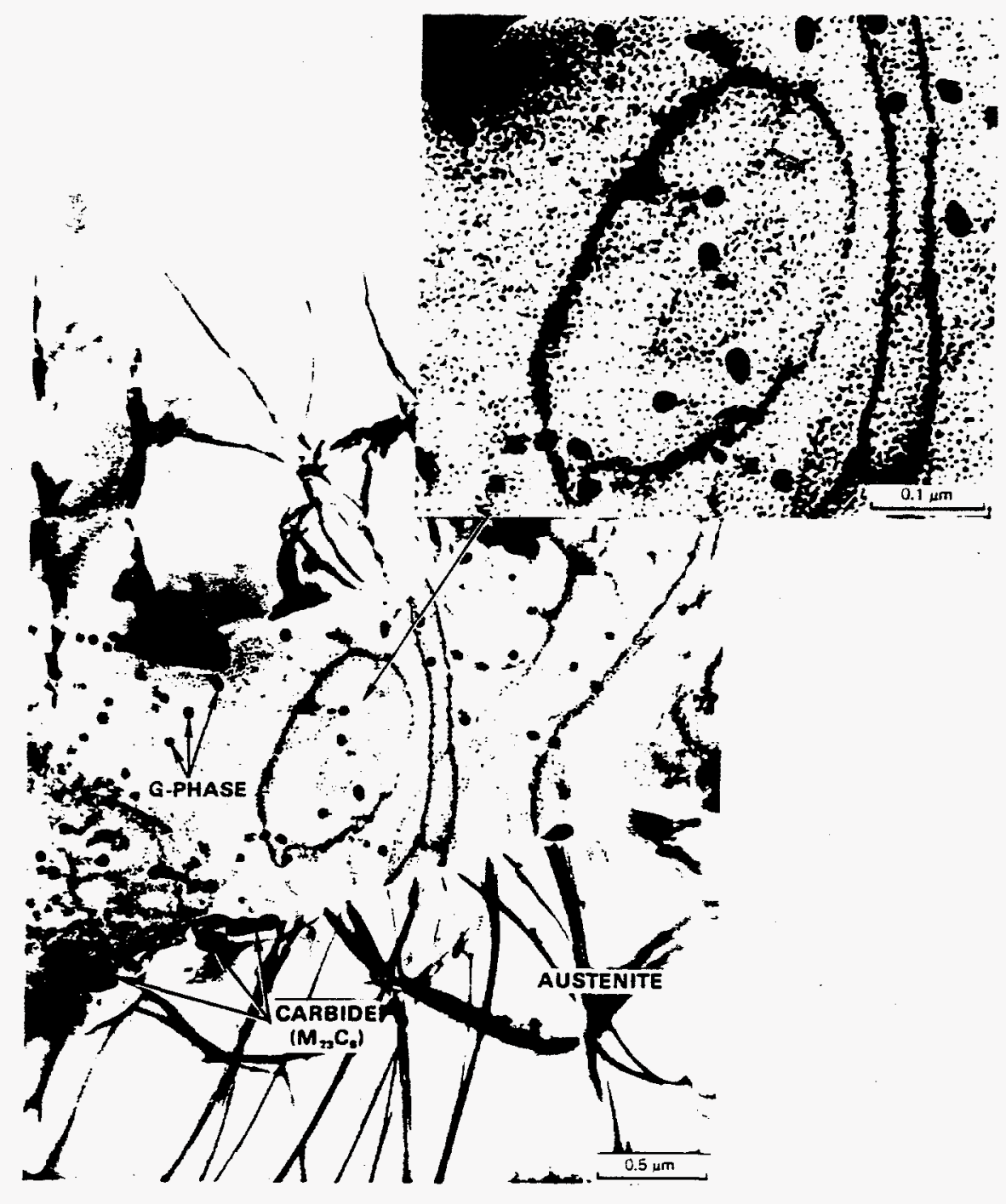

Figure 4. Electron micrograph of decomposed ferrite in a weld aged at $475^{\circ} \mathrm{C}$ for $5000 \mathrm{hr}$. The electron micrograph shows the G-phase, $M_{23} C_{6}$ carbides, and the mottled nature of the spinodally decomposed ferrite into $\alpha$ and $\alpha^{\prime}$ phases. 


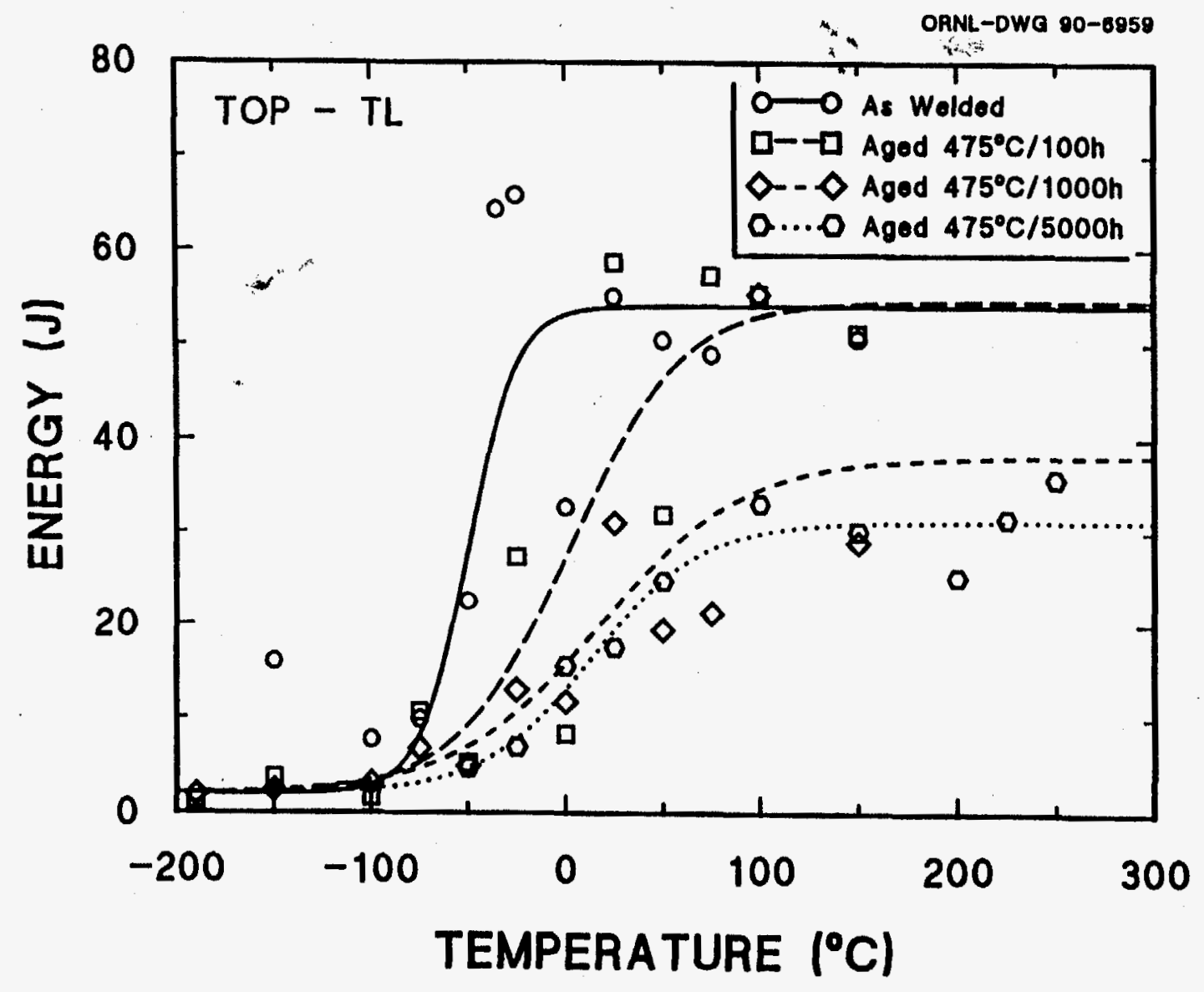

Figure 5. Charpy impact test results (impact energy vs test temperature) as a function of aging time at $475^{\circ} \mathrm{C}$ 